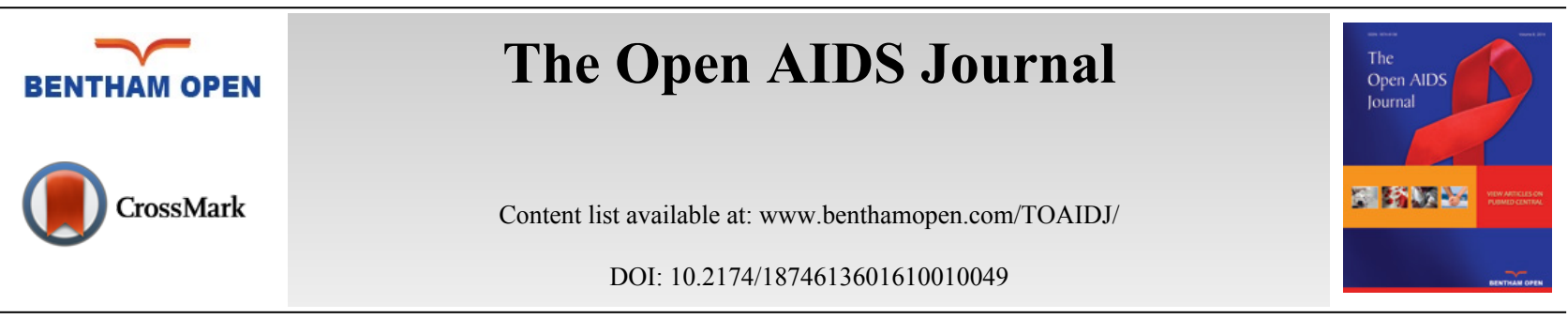

\title{
HIV Risk Among Men Who Have Sex With Men, Women Who Have Sex With Women, Lesbian, Gay, Bisexual and Transgender Populations in South Africa: A Mini-Review
}

\author{
Meredith G. B. Evans ${ }^{1, *}$, Allanise Cloete ${ }^{2}$, Nompumelelo Zungu ${ }^{2}$ and Leickness C. Simbayi ${ }^{2,3}$ \\ ${ }^{I}$ HUMA (Institute for Humanities in Africa) and Department of Sociology, University of Cape Town, Cape Town, \\ South Africa \\ ${ }^{2}$ HAST (HIVIAIDS, STIS and TB) Program, Human Sciences Research Council, Cape Town, South Africa \\ ${ }^{3}$ Department of Psychiatry \& Mental Health, University of Cape Town, Cape Town, South Africa
}

\begin{abstract}
:
Background:

The HIV epidemic in South Africa is characterized mainly by heterosexual transmission. Recently, the importance of targeting key populations and marginalized groups, including men who have sex with men (MSM) and transgender people, has been added to the national agenda.
\end{abstract}

\section{Objectives:}

This mini-review explores the current state of empirical research on HIV risk and MSM, women who have sex with women (WSW), lesbian, gay, bisexual and transgender (LGBT) populations in South Africa in order to assess the current state of research and identify gaps in the literature.

\section{Method:}

Peer-reviewed empirical social and behavioral articles on HIV prevalence and risk focusing on MSM, WSW, and LGBT populations published since 2006 were included in this mini-review.

\section{Results:}

In total 35 articles were included: 30 on MSM, gay, and/or bisexual male-identified populations, three on WSW, lesbian, and/or bisexual female-identified populations, two on LGB youth, and none on transgender populations.

\section{Conclusion:}

Despite South Africa being the country with the largest number of people living with HIV in the world, there is a limited amount of research in South Africa on HIV and non-normative gender identities and sexualities, especially WSW, lesbian, and/or bisexual female-identified populations, transgender populations, and LGB youth. Research with MSM, WSW, and LGBT populations should be prioritized in South Africa in order to appropriately inform HIV prevention strategies that meet the specific needs of these marginalized groups.

Keywords: Bisexuality, HIV, Homosexuality, Men who have sex with men, South Africa, Transgender persons, Women who have sex with women.

\footnotetext{
* Address correspondence to this author at the HUMA, Neville Alexander Building, University Avenue, University of Cape Town, Rondebosch, Cape Town 7700,Cape Town, South Africa; E-mail: mgbevans@gmail.com
} 


\section{BACKGROUND}

Since the 1990s, the HIV epidemic in South Africa has been understood as characterized mainly by heterosexual transmission $[1,2]$. Research and HIV prevention has therefore been focused primarily on HIV surveillance and intervention programs for the prevention of heterosexual transmission and prevention of mother-to-child transmission (PMTCT) [3]. Recently, key populations such as men who have sex with men (MSM), transgender people, sex workers, and injecting drug users (IDUs) have received greater attention in the context of a generalized HIV epidemic. In South Africa, the National Strategic Plan (NSP) on HIV, STIs and TB (2012-2016) promotes a broad framework for addressing HIV, focusing on prevention, care, treatment and support interventions based on risk and need [4]. The NSP (2012-2016) recognizes the importance of targeting key populations and marginalized groups, explicitly identifying MSM and transgender people as key populations [4].

In South Africa, Section 9 of the Constitution prohibits discrimination on the grounds of gender, sex, and sexual orientation [5]. Furthermore, South Africa was the fifth country in the world and the first in Africa to legalize same sex marriage [6]. Under this legislative framework, lesbian, gay, bisexual, and transgender (LGBT) people have a certain degree of visibility and protection in South Africa compared to many other countries around the world [7 - 9]. However, reports of hate crimes, violence and discrimination towards LGBT people remain persistent [10], suggesting a disjuncture between legislation declaring the right to equality and the realities of everyday life.

There is evidence of socio-cultural and structural risk factors that play a role in increasing HIV risk for MSM, women who have sex with women (WSW), and LGBT people. Gay, bisexual, and other MSM are at high risk for HIV infection as a result of individual level risks such as unprotected anal intercourse (UAI), having multiple sexual partners, IDU and other drug use [11 - 14]. Since the onset of the generalized HIV epidemic in sub-Saharan Africa, documenting HIV prevalence, incidence and risk behaviors of MSM was neglected [13, 15 - 19]. However, HIV has been a concern for LGBT populations in South Africa since the first HIV cases in the country were identified among gay men in the 1980s [2]. Until 2007, targeted sexual health information and services for MSM were implemented by the few LGBT organizations in South Africa [20]. The 2007-2011 NSP on HIV/AIDS and STIs in South Africa [3] drew attention for the first time to the lack of HIV prevalence data and tailored HIV prevention services for MSM [21]. HIV bio-behavioral surveys in African countries increasingly indicate that MSM have high HIV prevalence rates [11, 20 - 27] and high HIV incidence rates [27 - 29]. Although often misperceived as isolated, there is evidence of overlap between the homosexual and heterosexual populations with reports of bisexual activity among men [30, 31]. Despite the evidence that same-sex sexualities are not only indigenous but also widespread in African contexts, samesex sexualities are still widely perceived as 'unAfrican' [8, 9, 32 - 38]. In this context, MSM are considered a "hard-toreach" population and are consequently thought of as epidemiologically invisible [39].

There is also a widespread misconception that lesbian, bisexual and other WSW are not at risk of HIV. Such misconceptions are held not only by the general public but even by healthcare providers and WSW themselves [40 - 43]. This myth is reinforced by policy and programs that continue to exclude WSW. For example, although the terminology WSW is defined in the South African NSP on HIV, STIs and TB (2012-2016), WSW are not identified as a population at risk of HIV [4]. Due to misconceptions that WSW are not at risk of HIV or other STIs, many may not practice safer sex strategies [2, 44, 45] or have knowledge about barrier methods [46]. Contrary to misconceptions, HIV can be transmitted as a result of sex between women through blood, menstrual blood, breast milk and vaginal secretions [47]. Furthermore, lesbian, bisexual and other WSW do not necessarily only have sex with other women, as sexual contact with men has been found to occur frequently among lesbian-identified and other WSW [48 - 51]. WSW have been found to be more likely to have high risk partners, including MSM and IDUs, compared to women who had never had sex with other women [52]. Studies have also shown that WSW are at high risk of violence (including sexual violence and rape), discrimination, and substance use [53] which can augment risk of HIV infection. In South Africa, homophobic and transphobic sexual violence targeted at lesbian, bisexual and other WSW, as well as toward transgender populations (colloquially referred to as "corrective rape") is an especially concerning risk factor [54].

Too often, transgender people have been excluded from HIV prevalence and behavioral research [55]. The high risk for HIV infection among transgender people has been shown globally; however, more often than not HIV prevalence data on transgender people are missing from country reports [14]. Although transgender people (including transgender women, transgender men, and gender queer or non-binary ${ }^{a}$ people) share risk factors such as transphobia and cissexism, social isolation, violence, and unmet healthcare needs [56], unique and varied biological and behavioral risk factors have been identified for transgender women and transgender men. 
Transgender women have long been known to be at especially high risk for HIV infection and transmission [14]. The high risk of infection is driven in part by frequently reported engagement in unprotected receptive anal intercourse with cisgender ${ }^{\mathrm{b}}$ men $[14,57]$. Because of this shared biological risk, in the past transgender women have been subsumed under the category MSM. However, this is a problematic categorization as it misgenders transgender women. Furthermore, transgender women have specific needs and risk factors [55]. Lack of data on the HIV epidemic among transgender women remains a challenge. In a systematic review and meta-analysis, HIV data on transgender women were only available for countries with HIV epidemics concentrated among MSM, including the United States, six AsiaPacific countries, five Latin American countries, and three European countries [14].

Limited research exists on the HIV risk factors among transgender men [56]. One of the explanations for the lack of research on transgender men and HIV is the assumption that transgender men are only having sex with cisgender women [58]. The corresponding misconception is that HIV cannot be transmitted through sex between transgender men and cisgender women. Similar to HIV transmission risk for WSW, HIV can be transmitted as a result of sex between transgender men who have sex with other transgender men or cisgender women through blood, menstrual blood, breast milk and vaginal secretions [47]. Furthermore, some transgender men engage in unprotected receptive vaginal and/or anal intercourse with cisgender men, also referred to as transgender men who have sex with men [59, 60]. HIV risk behaviors have been found to be high among transgender men who have sex with men. A study in the United States found a majority of trans MSM reported not using condoms consistently during receptive anal and/or vaginal intercourse with cisgender men [61]. High sexual risk-taking behavior, including sex without condoms or other barrier methods such as dental dams, finger condoms, and gloves, has also been reported among transgender men regardless of partners' gender [61].

In addition to biological and behavioral risk factors, widespread homophobia and heterosexism, as well as transphobia and cissexism, marginalizes MSM, WSW, and LGBT populations. This social vulnerability can increase risk for HIV infection. It is well-documented that social exclusion and stigmatization increase vulnerability to HIV in a variety of ways, such as by increasing risk-taking behavior [22, 59, 62], by being targeted for physical or sexual violence and by negatively impacting mental health [63].

Sexual identity and behavior is complex, and MSM, WSW, and LGBT populations are diverse. HIV risk overlaps between LGBT populations and the general heterosexual population, as some heterosexual-identified individuals engage in same-sex sexual practices and some LGB-identified individuals engage in heterosexual practices [64]. Inequalities of sexuality and gender identity are compounded by intersecting inequalities such as race, class, and ability, all of which can complicate HIV risk. In order to appropriately manage the HIV epidemic, the South African research agenda should address the HIV risk needs of MSM, WSW, and LGBT populations, and not only HIV within the general heterosexual cisgender population. Research on MSM, WSW, and LGBT populations is necessary to appropriately inform HIV prevention policies, strategies, and programs. This mini-review explores the current state of empirical research on HIV risk and MSM, WSW, and LGBT populations in South Africa in order to assess the current state of research and identify gaps in the literature.

\section{METHOD}

A rapid scoping mini-review was conducted in 2014 mid-year (July-August). It included peer-reviewed empirical social and behavioral articles on HIV prevalence and risk for LGBT populations in South Africa published between 2006 and 2014. A desktop review was initially conducted on articles published at any time; however, the majority of articles were found published from 2008. This surge in research among LGBT populations corresponds with the release of the NSP on HIV/AIDS and STIs in South Africa for 2007-2011, which specified MSM for the first time as an at-risk population. Therefore, a decision was made to limit the literature review to articles published from 2006, the year preceding the launch of the NSP, to 2014. Literature searches were conducted on PubMed (http://www.ncbi.nlm.nih.gov/pubmed) using the following Medical Subject Headings (MeSH): homosexuality, bisexuality, transgendered persons, South Africa, and HIV. PubMed searches yielded 70 abstracts, and after review 30 articles met the inclusion criteria. Additional searches were conducted on Google Scholar (www.Scholar.Google.co.za)

${ }^{\mathrm{a}}$ Gender queer or non-binary describes people who do not subscribe to binary gender identities (man/woman) and who identify with neither, both, or a combination of masculinity and femininity. In this review, transgender is used broadly as an umbrella term to encompass gender queer or non-binary persons.

${ }^{\mathrm{b}}$ Cisgender describes individuals whose gender identity reflects their assigned biological sex, i.e. cisgender woman refers to a female-bodied person identifying as a woman. 
for key title terms of "HIV"; "South Africa", "South African", and at least one of the following terms: "men who have sex with men", "MSM", "women who have sex with women", "WSW", "lesbian", "gay", "bisexual", "transgender(ed)", "LGBT(QI)", GLBT(QI)", or "queer," and an additional two articles met inclusion criteria.

\section{RESULTS}

This review found 35 studies in total; 30 on MSM, gay, and/or bisexual male-identified populations, three on WSW, lesbian, and/or bisexual female-identified populations, two on LGB youth, and none on transgender populations.

\section{HIV Prevalence Estimates and Risk Behavior Among Gay, Bisexual, and Other MSM}

In recent years, there has been an upsurge in HIV bio-behavioral surveys conducted among MSM in major cities of South Africa, and more recently in smaller towns and cities. As shown in Table 1, five articles were found to report on four HIV bio-behavioral surveys conducted among MSM in South Africa and include HIV prevalence estimates [59, 67 - 70]. The four HIV bio-behavioral surveys conducted among MSM were: the Johannesburg/eThekwini Men's Study (JEMS) [21], The Cape Town's Men's Study [67, 68], The Soweto Men's Study [66], and The Mpumalanga Men's Study [65]. Of the four surveys, three used respondent driven sampling (RDS) to recruit MSM, and one used venuebased sampling [67, 68]. In all studies, HIV prevalence estimates revealed that MSM were at least four times more at risk of HIV infection than their heterosexual counterparts. The HIV prevalence among MSM ranged from $10.0 \%$ to $50.0 \%$.

Similarities in terms of socio-demographic characteristics were apparent across all four studies. For instance, study participants tended to be young, gay-identified, and black South African ${ }^{\mathrm{c}}$ [28]. In a review of studies done elsewhere, including other African countries [22], it was found that MSM samples have tended to be young $(<25$ years of age) and gay-identified. Although in the four surveys MSM samples overwhelmingly identified as gay, bisexual behavior appeared to be common among MSM in South Africa. The surveys found multiple sexual partnerships with men and women to be common. Research has shown that bisexual behavior among MSM is common in African contexts [11, 23, 69,70 ] with some MSM also having concurrent male and female sexual partners [64]. HIV prevalence was found to be associated with age (older MSM were more at risk) $[66,68]$ and sexual orientation identity, with MSM who selfidentify as gay being more likely to be HIV positive [21, 66 - 67].

\section{Behavioral, Social and Structural Risks Among Gay, Bisexual, and Other MSM}

This review found 10 studies focused on behavioral risks among gay, bisexual, and other MSM that did not report HIV prevalence estimates using HIV testing (Table 2). One study did however include self-reported HIV status among MSM who had previously tested, which was found to be $14.1 \%$ [25].

Studies with general male populations found increased risk among men who engaged in MSM behavior. In a study with men in the Eastern Cape, it was found that having had sex with a man significantly increased the odds of HIV infection [71]. In a study conducted in Cape Town among men in shebeens ${ }^{i}$ it was found men who reported sex with men and women were more likely than men who had sex with women only to report an HIV positive status, a history of being diagnosed with an STI, and to have perpetrated violence against an intimate partner [72].

In a study among black South African MSM in Gauteng, 59.0\% (N=199) reported having UAI in the past six months [20]. The risk behavior of UAI was positively associated with the consumption of alcohol, and negatively associated with the exclusive use of water-based lubricants [20]. This study found high prevalence of substance use among MSM: $38.0 \%$ of participants reported getting drunk at least once a week and 30.0\% reported using marijuana, but less than 5.0\% reported using other drugs [20]. The prevalence of UAI among South African MSM was estimated to be as high as $45.8 \%(\mathrm{~N}=542)$ [20]. Other studies reported even higher rates of UAI. A study among MSM using venuebased sampling, estimated the prevalence of UAI at 49.3\% ( $=200)$ among black and coloured MSM in peri-urban Cape Town [67]. According to findings from the Soweto Men's study, it was reported that two thirds of MSM sampled had multiple sexual partners in the past six months and nearly half of the sample reported UAI [73]. Another study among MSM found that UAI was related to non-regular same neighborhood partners and familiar (previously known) partners compared to similar (age-race-economic) partnership types [74].

${ }^{\mathrm{c}}$ According to the Population Registration Act of 1950, under apartheid South Africans were classified into the racial categories of black African, colored, Indian/Asian, and white. These racial categories are still used today by Statistics South Africa and other research programs in order to measure and reflect ongoing inequalities across racial lines. 
Table 1. Literature on HIV prevalence estimates and risk behavior among gay, bisexual and other MSM in South Africa $(\mathbf{N}=5)$.

\begin{tabular}{|c|c|c|c|c|c|c|c|c|}
\hline Source & Sample size & \begin{tabular}{|c|}
$\begin{array}{c}\text { Age } \\
\text { range }\end{array}$ \\
\end{tabular} & Study site & $\begin{array}{c}\text { Study } \\
\text { year }\end{array}$ & Study design & \begin{tabular}{|c|} 
Study \\
method
\end{tabular} & $\begin{array}{l}\text { Overall HIV } \\
\text { Prevalence }\end{array}$ & Key findings \\
\hline $\begin{array}{l}\text { Lane et al. (2014) ("The } \\
\text { Mpumalanga Men's Study") }\end{array}$ & $\begin{array}{c}\text { Gert Sibande } \\
(\mathrm{n}=307) \\
\text { Ehlanzeni } \\
(\mathrm{n}=298) \\
\text { Total }=605 \\
\text { MSM }\end{array}$ & $18+$ & $\begin{array}{c}\text { Urban Free State, } \\
\text { Gert Sibande \& } \\
\text { Ehlanzeni }\end{array}$ & 2013 & $\begin{array}{l}\text { RDS, rapid } \\
\text { finger-prick } \\
\text { HIV testing }\end{array}$ & Survey & \begin{tabular}{|c|} 
Gert \\
Sibande $=28.3 \%$ \\
Ehlanzeni $=13.7 \%$
\end{tabular} & $\begin{array}{c}\text { Among MSM sampled } \\
\text { few were aware of their } \\
\text { HIV positive status, } \\
\text { although regular HIV } \\
\text { testing appeared to be } \\
\text { common in both } \\
\text { districts. }\end{array}$ \\
\hline $\begin{array}{l}\text { Baral } \text { et al. }(2011)^{\mathrm{e}} \text { ("The } \\
\text { Cape Town's Men's Study") }\end{array}$ & $200 \mathrm{MSM}$ & $18+$ & $\begin{array}{l}\text { Peri-urban Cape } \\
\text { Town }\end{array}$ & 2009 & $\begin{array}{l}\text { Venue based } \\
\text { sampling, } \\
\text { Rapid oral } \\
\text { testing }\end{array}$ & Survey & $25.5 \%$ & \begin{tabular}{|c|} 
HIV positive status was \\
associated with \\
inconsistent condom use \\
with male partners, \\
having been \\
blackmailed, being over \\
26 years old, being \\
unemployed, and rural \\
origin. \\
\end{tabular} \\
\hline $\begin{array}{l}\text { Burrell et al. (2010) ("The } \\
\text { Cape Town's Men's Study") }\end{array}$ & $542 \mathrm{MSM}$ & $18+$ & $\begin{array}{l}\text { Urban/peri-urban } \\
\text { Cape Town }\end{array}$ & 2009 & $\begin{array}{l}\text { Venue based } \\
\text { sampling, } \\
\text { Rapid oral } \\
\text { testing }\end{array}$ & Survey & $10.4 \%$ & \begin{tabular}{|l} 
HIV positive status was \\
associated with self- \\
identifying as gay, \\
homosexual or queer, \\
and reporting having \\
had a STI. Bisexual \\
activity was reported by \\
$17.1 \%$ of the sample. \\
\end{tabular} \\
\hline $\begin{array}{l}\text { Rispel et al. (2011) (“The } \\
\text { Johannesburg/EThekwini } \\
\text { Men's Study: JEMS”) }\end{array}$ & $\begin{array}{c}\text { Durban }(\mathrm{n}= \\
85) \\
\text { Johannesburg } \\
(\mathrm{n}=200) \\
\text { Total }=285 \\
\text { MSM }\end{array}$ & $18+$ & $\begin{array}{c}\text { Urban, } \\
\text { Johannesburg and } \\
\text { Durban }\end{array}$ & 2008 & $\begin{array}{l}\text { RDS, rapid } \\
\text { finger-prick } \\
\text { HIV testing }\end{array}$ & Survey & $\begin{array}{c}\text { Durban }=27.5 \% \\
\text { Johannesburg }= \\
49.5 \%\end{array}$ & \begin{tabular}{|c|} 
HIV positive status was \\
associated with being \\
gay-identified, receptive \\
UAI, sex with a person \\
known to be HIV \\
positive, and an STI \\
diagnosis. \\
\end{tabular} \\
\hline $\begin{array}{l}\text { Lane et al. (2011) ("The } \\
\text { Soweto Men's Study") }\end{array}$ & $278 \mathrm{MSM}$ & $18+$ & $\begin{array}{l}\text { Peri-urban } \\
\text { township of } \\
\text { Soweto }\end{array}$ & 2008 & $\begin{array}{l}\text { RDS, rapid } \\
\text { HIV testing } \\
\text { of blood } \\
\text { samples }\end{array}$ & Survey & $13.2 \%$ & \begin{tabular}{|c|} 
HIV positive status was \\
associated with being \\
older than 25 , gay- \\
identified, having \\
monthly income less \\
than ZAR500 (US\$50), \\
exchanging alcohol or \\
drugs for sex, \\
unprotected reciprocal \\
anal intercourse, and \\
reporting 6-9 partners in \\
the prior 6 months.
\end{tabular} \\
\hline
\end{tabular}

$\left.{ }_{\mathrm{d}}^{\mathrm{d}} 65\right],{ }^{\mathrm{e}}[68],{ }^{\mathrm{f}}[67],{ }^{\mathrm{g}}[21],{ }^{\mathrm{h}}[66]$

Structural violence, high levels of poverty, unemployment, and an intolerant and homophobic cultural and social context were structural risk factors found among MSM in Cape Town [75]. Finally, an online study of MSM found that childhood sexual assault increased HIV risk [76].

\section{HIV Testing, Disclosure and Knowledge Among Gay, Bisexual, and Other MSM}

HIV counselling and testing (HCT), status disclosure, and knowledge are promoted by HIV prevention programs. Literature on HIV testing, disclosure and knowledge among gay, bisexual, and other MSM is shown in Table 3. Assessing the accessibility and uptake of HCT for marginalized groups including MSM, WSW, and LGBT populations is essential. Four studies addressed the issue of HCT among MSM. One study found that the most cited reason for MSM not testing for HIV was low risk perception and fear of being tested [77]. Two studies showed high levels of acceptability of couples-based HCT among MSM [78, 79]. Another community-based survey with MSM (N=300) in urban and peri-urban areas in the city of Pretoria found that MSM in socially vulnerable positions were less likely to get 
tested for HIV [80]. Specifically, living in a townshipt, being black South African, and lacking HIV knowledge decreased likelihood of ever having tested for HIV [80].

Table 2. Literature on behavioral, social and structural factors contributing to HIV risk among gay, bisexual, and other MSM in South Africa (N=10).

\begin{tabular}{|c|c|c|c|c|c|c|c|}
\hline Source & $\begin{array}{l}\text { Sample } \\
\text { size }\end{array}$ & $\begin{array}{c}\text { Age } \\
\text { range }\end{array}$ & Study site & $\begin{array}{l}\text { Study } \\
\text { year }\end{array}$ & Study design & $\begin{array}{c}\text { Study } \\
\text { methods }\end{array}$ & Key findings \\
\hline $\begin{array}{c}\text { Heusser \& } \\
\text { Elkonin }(2013)^{\mathrm{j}}\end{array}$ & $237 \mathrm{MSM}$ & $18+$ & $\begin{array}{l}\text { South Africa } \\
\text { (online) }\end{array}$ & n.d. & $\begin{array}{l}\text { Online, recruited via } \\
\text { emails through South } \\
\text { African dating site }\end{array}$ & $\begin{array}{l}\text { Survey } \\
\text { (online) }\end{array}$ & $\begin{array}{l}\text { Participants who experienced childhood } \\
\text { sexual assault were more likely to report } \\
\text { dissociation and depression, drug use, } \\
\text { drug use before sex, one-night stands, } \\
\text { and recent abusive relationship. }\end{array}$ \\
\hline $\begin{array}{l}\text { Imrie et al. } \\
(2013)^{\mathrm{k}} \\
\text { ("Impilo } \\
\text { Yamadoda") }\end{array}$ & $\begin{array}{c}223 \text { Zulu } \\
\text { males }\end{array}$ & $18-35$ & $\begin{array}{c}\text { Rural, Hlabisa sub- } \\
\text { district, } \\
\text { Kwazulu-Natal }\end{array}$ & n.d. & $\begin{array}{l}\text { Prospective cohort } \\
\text { study }\end{array}$ & Survey $(\mathrm{x} 4)$ & $\begin{array}{c}3.1 \%(\mathrm{n}=7) \text { reported sex with a man in } \\
\text { the last } 3 \text { months and all reported female } \\
\text { partner(s). }\end{array}$ \\
\hline $\begin{array}{l}\text { Eaton et al. } \\
\qquad(2013)^{1}\end{array}$ & $\begin{array}{c}1060 \\
\text { MSW \& } \\
143 \\
\text { MSMW }\end{array}$ & $\begin{array}{l}\text { Mean 31 } \\
\text { MSW \& } \\
28 \\
\text { MSMW }\end{array}$ & $\begin{array}{l}\text { Shebeens, } \\
\text { Peri-urban, } \\
\text { township in Cape } \\
\text { Town. }\end{array}$ & 2009-11 & $\begin{array}{l}\text { Priorities for Local } \\
\text { AIDS Control } \\
\text { Efforts (PLACE) } \\
\text { community mapping } \\
\text { methodology }\end{array}$ & Survey & $\begin{array}{l}\text { MSM as well as women were twice as } \\
\text { likely to report being HIV positive and } \\
\text { to report high levels of risk taking } \\
\text { compared to men who had sex with } \\
\text { women only. }\end{array}$ \\
\hline $\begin{array}{l}\text { Jobson et al. } \\
(2013)^{\mathrm{m}}\end{array}$ & $31 \mathrm{MSM}$ & N/A & $\begin{array}{c}\text { Peri-urban, } \\
\text { townships of Cape } \\
\text { Town }\end{array}$ & 2009 & Purposive sampling & $\begin{array}{c}\text { Interviews \& } \\
\text { focus group } \\
\text { discussions } \\
\text { (FGDs) }\end{array}$ & $\begin{array}{l}\text { Factors that increased HIV risk: } \\
\text { structural violence with high levels of } \\
\text { poverty and unemployment, and an } \\
\text { intolerant and homophobic cultural and } \\
\text { social context. }\end{array}$ \\
\hline $\begin{array}{l}\text { Arnold et al. } \\
(2013)^{\mathrm{n}} \\
\text { ("Soweto Men's } \\
\text { Study") }\end{array}$ & 377 MSM & $18+$ & $\begin{array}{c}\text { Peri-urban } \\
\text { township, Soweto, } \\
\text { Gauteng }\end{array}$ & 2008 & $\begin{array}{l}\text { Rapid HIV testing } \\
\text { using blood samples }\end{array}$ & Survey & $\begin{array}{l}\text { Factors that increased risk of UAI: } \\
\text { Increased length of partnerships, number } \\
\text { of sexual episodes with partner, } \\
\text { "regular" partner type, experiences of } \\
\text { homonegativity, lack of self-efficacy, } \\
\text { low income, and being circumcised. }\end{array}$ \\
\hline $\begin{array}{l}\text { Dunkle et al. } \\
(2013)^{\circ}\end{array}$ & $\begin{array}{c}1220 \\
\text { males }\end{array}$ & $18-49$ & $\begin{array}{c}\text { Urban/Rural, } \\
\text { Eastern Cape \& } \\
\text { KwaZulu-Natal }\end{array}$ & 2008 & $\begin{array}{c}\text { Multistage } \\
\text { proportionate } \\
\text { sampling design, dried } \\
\text { blood spots for HIV } \\
\text { testing }\end{array}$ & Survey & $\begin{array}{c}27.4 \% \text { reported any consensual MSM } \\
\text { contact; } 31.4 \% \text { reported oral/anal MSM } \\
\text { contact. }\end{array}$ \\
\hline $\begin{array}{l}\text { Sandfort et al. } \\
(2013)^{\mathrm{p}}\end{array}$ & $300 \mathrm{MSM}$ & $18-40$ & $\begin{array}{l}\text { Urban and peri- } \\
\text { urban Pretoria }\end{array}$ & 2008 & Targeted recruitment & Surveys & $\begin{array}{l}\text { Factors that increased risk of UAI: } \\
\text { Partnership types of non-regular same } \\
\text { neighborhood partners and familiar } \\
\text { partners compared to similar (age-race- } \\
\text { economic) partnership types. }\end{array}$ \\
\hline $\begin{array}{l}\text { Lane et al. } \\
\qquad(2008)^{\mathrm{q}}\end{array}$ & $\begin{array}{c}199 \text { black } \\
\text { MSM }\end{array}$ & $18+$ & $\begin{array}{c}\text { Peri-urban } \\
\text { townships, Gauteng }\end{array}$ & $2004-5$ & Purposive sampling & Survey & $\begin{array}{l}59.0 \% \text { reported UAI. Factors that } \\
\text { increase risk of UAI included: regular } \\
\text { drinking, regular drinking to } \\
\text { intoxication, and reporting symptoms of } \\
\text { rectal trauma resulting from anal } \\
\text { intercourse. }\end{array}$ \\
\hline $\begin{array}{l}\text { Sandfort et al. } \\
(2008)^{\mathrm{r}}\end{array}$ & $\begin{array}{l}1045 \\
\text { MSM }\end{array}$ & $16+$ & $\begin{array}{c}\text { Gauteng, } \\
\text { KwaZulu-Natal, \& } \\
\text { Western Cape }\end{array}$ & $\begin{array}{c}2003 \& \\
2005\end{array}$ & \begin{tabular}{|c|} 
Purposive non- \\
proportional quota \\
sample, self-reported \\
status
\end{tabular} & Survey & $\begin{array}{l}\text { Self-reported HIV prevalence (among } \\
\text { previously tested) was } 14.1 \% \text {. High } \\
\text { levels of testing were reported }(69.7 \%) \text {. } \\
\text { HIV infection was associated with lower } \\
\text { education and knowing other PLHIV. }\end{array}$ \\
\hline $\begin{array}{l}\text { Jewkes et al. } \\
(2006)^{\mathrm{s}}\end{array}$ & $\begin{array}{c}1277 \\
\text { Xhosa } \\
\text { males }\end{array}$ & $15-26$ & $\begin{array}{l}\text { Rural, } 70 \text { villages, } \\
\text { Eastern Cape }\end{array}$ & $2002-3$ & \begin{tabular}{|c|} 
Randomized \\
controlled trial, blood \\
testing for HIV
\end{tabular} & Survey & $\begin{array}{l}\text { Having had sex with a man significantly } \\
\text { increasing odds of HIV infection (OR } \\
3.61) \text {. }\end{array}$ \\
\hline
\end{tabular}

${ }_{\mathrm{j}}^{\mathrm{j}}[76],{ }^{\mathrm{k}}[31],{ }^{\mathrm{l}}[72],{ }^{\mathrm{m}}[75],{ }^{\mathrm{n}}[73],{ }^{\mathrm{o}}[30],{ }^{\mathrm{p}}[74],{ }^{\mathrm{q}}[20],{ }^{\mathrm{r}}[25],{ }^{\mathrm{s}}[71]$

Disclosure of HIV status was explored in one study that found 59.0\% (N=300) of MSM disclosed their status to sexual partners [81]. Two studies explored HIV knowledge among MSM. The first study found that HIV knowledge levels for MSM in South Africa were high [82] and the second found that HIV conspiracy beliefs, such as AIDS information being held back from the general public, were endorsed by $22.9 \%(\mathrm{~N}=324)$ of the sample of MSM [83].

${ }^{t}$ In South Africa, townships are urban housing areas, usually on the margins of towns and cities, that, as a legacy of the colonial and apartheid systems, still tend to be underdeveloped and segregated along racial lines. 
Table 3. Literature on HIV testing, disclosure and knowledge among gay, bisexual and other MSM in South Africa (N=7).

\begin{tabular}{|c|c|c|c|c|c|c|c|}
\hline Source & $\begin{array}{c}\text { Sample } \\
\text { size }\end{array}$ & \begin{tabular}{c|} 
Age \\
range
\end{tabular} & Study site & Study year & Study design & Study methods & Key findings \\
\hline $\begin{array}{l}\text { Stephenson } \\
\text { et al. }(2013)^{\mathrm{u}}\end{array}$ & $36 \mathrm{MSM}$ & $18+$ & $\begin{array}{l}\text { Urban \& peri-urban } \\
\text { townships, Cape } \\
\text { Town }\end{array}$ & $\begin{array}{c}\text { June-July } \\
2010 \text { \& Jan } \\
2011\end{array}$ & $\begin{array}{l}\text { Venue-based } \\
\text { purposive } \\
\text { sampling }\end{array}$ & $\begin{array}{l}\text { FGDs and in-depth } \\
\text { interviews }\end{array}$ & $\begin{array}{c}\text { High levels of acceptability of } \\
\text { couples-based HCT services catered } \\
\text { towards MSM were reported. }\end{array}$ \\
\hline $\begin{array}{l}\text { Stephenson } \\
\text { et al. }(2012)^{\mathrm{v}}\end{array}$ & $486 \mathrm{MSM}$ & $18+$ & South Africa & $\begin{array}{l}\text { June and } \\
\text { July } 2010 \\
\end{array}$ & $\begin{array}{c}\text { Online } \\
\text { recruitment }\end{array}$ & Internet-based survey & $\begin{array}{l}89.0 \% \text { acceptability of couples- } \\
\text { based HCT. }\end{array}$ \\
\hline $\begin{array}{l}\text { Wagenaar, } \\
\text { et al. }(2012)^{\mathrm{w}}\end{array}$ & \begin{tabular}{|c|}
1154 \\
MSM \\
(USA) \& \\
439 MSM \\
(SA) \\
\end{tabular} & $18+$ & $\begin{array}{l}\text { South Africa and the } \\
\text { USA }\end{array}$ & 2010 & $\begin{array}{l}\text { Online } \\
\text { recruitment }\end{array}$ & Internet-based survey & $\begin{array}{l}\text { HIV knowledge levels were high for } \\
\text { South African MSM (median score } \\
16 / 18 \text { ). }\end{array}$ \\
\hline $\begin{array}{l}\text { Tun et al. } \\
(2012)^{\mathrm{x}}\end{array}$ & $324 \mathrm{MSM}$ & $18+$ & $\begin{array}{c}\text { Urban and peri-urban, } \\
\text { Pretoria } \\
\text { \&Attridgeville }\end{array}$ & 2009 & RDS & $\begin{array}{l}\text { Cross-sectional } \\
\text { survey }\end{array}$ & $\begin{array}{c}22.9 \% \text { endorsed HIV conspiracy } \\
\text { beliefs (AIDS information held back } \\
\text { from the public, HIV as a man-made } \\
\text { virus, \& people being used as guinea } \\
\text { pigs in HIV research). }\end{array}$ \\
\hline $\begin{array}{l}\text { Knox et al. } \\
(2013)^{y}\end{array}$ & $300 \mathrm{MSM}$ & $18-40$ & \begin{tabular}{|c|} 
Urban and peri-urban \\
Pretoria \\
\end{tabular} & 2008 & $\begin{array}{c}\begin{array}{c}\text { Purposive } \\
\text { sampling }\end{array} \\
\end{array}$ & Survey & $\begin{array}{c}59.0 \% \text { practiced communication of } \\
\text { HIV status to partners. }\end{array}$ \\
\hline $\begin{array}{l}\text { Knox et al. } \\
\quad(2011)^{\mathrm{z}}\end{array}$ & $300 \mathrm{MSM}$ & $18-40$ & $\begin{array}{c}\text { Urban and peri-urban } \\
\text { Pretoria }\end{array}$ & 2008 & $\begin{array}{l}\text { Purposive } \\
\text { sampling }\end{array}$ & $\begin{array}{l}\text { Community-based } \\
\text { survey }\end{array}$ & $\begin{array}{c}67.7 \% \text { had ever tested for HIV. } \\
\text { Social vulnerability (being black, } \\
\text { living in a township, and lacking } \\
\text { HIV knowledge) reduced likelihood } \\
\text { of testing. Low income \& not self- } \\
\text { identifying as gay reduced repeat } \\
\text { testing. Low income and } \\
\text { internalized homophobia reduced } \\
\text { recent testing. }\end{array}$ \\
\hline $\begin{array}{l}\text { Nel et al. } \\
(2013)^{\text {aa }}\end{array}$ & $\begin{array}{l}1045 \\
\text { MSM }\end{array}$ & $16+$ & $\begin{array}{l}\text { Gauteng, KwaZulu- } \\
\text { Natal, Western Cape }\end{array}$ & 2003,2005 & $\begin{array}{c}\text { Purposive } \\
\text { sampling of } \\
\text { LGBT persons }\end{array}$ & Survey & $\begin{array}{c}27.0 \% \text { never tested for HIV. Most } \\
\text { frequent reason for not testing was } \\
\text { the perception of not being at risk } \\
(57.0 \%) \text { and fear of being tested } \\
(52.0 \%)\end{array}$ \\
\hline
\end{tabular}

${ }^{\mathrm{u}}[79],{ }^{\mathrm{v}}[78],{ }^{\mathrm{w}}[82],{ }^{\mathrm{x}}[83],{ }^{\mathrm{y}}[81],{ }^{\mathrm{z}}[80],{ }^{\mathrm{aa}}[77]$

\section{Stigma, Mental Health, and Drug Use Among Gay, Bisexual, and Other MSM}

This review found evidence of stigma towards MSM, internalized homophobia, poor mental health, and risk of drug use among gay, bisexual and other MSM (see Table 4). High levels of internalized homophobia were found in a study among MSM in Pretoria [84]. In a study in Soweto it was found that black African MSM reported a lack of nonstigmatizing sexual health care services and that they often had to hide their sexuality when accessing health care services for fear of being stigmatized [17]. Fear of disclosing sexual practices and identity to health workers was also reported in a study conducted among MSM in Durban, Johannesburg and Pietermaritzburg [85].

A study of HIV positive MSM in Cape Town found high levels of internalized HIV-related stigma, with $55.0 \%$ of HIV positive MSM concealing their HIV status from others, and 64.0\% reporting difficulties with disclosing their status [86]. According to the results of this study, MSM living with HIV experienced similar levels of HIV-related stigma as men who had sex with women only. However, MSM living with HIV were at risk of both HIV-related stigma and sexuality-related stigma [86].

Two studies found that MSM who experienced homophobia and/or depression were more likely to engage in risky sex through UAI [87, 88]. For MSM using drugs, HIV prevalence was estimated at 35.0\% [89, 90]. Drug use was found to have facilitated risky sex among MSM, including inconsistent condom use [89, 90].

\section{HIV Risk Among Lesbian, Bisexual, and Other WSW in South Africa}

As shown in Table 5, only three studies were found to include WSW and HIV in South Africa [41, 91, 92]. These included: a quantitative study with WSW in South Africa as well as Botswana, Namibia, and Zimbabwe [91]; a qualitative study on self-identified lesbians living with HIV in Namibia, South Africa, and Zimbabwe [41]; and a quantitative study on WSW living with HIV in South Africa [92].

Only one study provided a self-reported HIV prevalence estimate of 9.6\% (N=591) for WSW in Southern Africa 
[91]. Data were combined across four Southern African countries (Botswana, Namibia, South Africa, and Zimbabwe) and the sample was not representative. Having experienced sexual violence from men and/or women were factors that increased odds of self-reported HIV infection among women in the study. Nearly 1 in 5 respondents reported transactional sex and nearly 1 in 3 respondents reported having been raped in the study. Approximately half of the sample reported having ever had consensual heterosexual sex.

Table 4. Literature on HIV risk and gay, bisexual, and other MSM in South Africa: stigma, mental health, and drug use $(\mathbf{N}=\mathbf{8})$.

\begin{tabular}{|c|c|c|c|c|c|c|c|}
\hline Source & $\begin{array}{l}\text { Sample } \\
\text { size }\end{array}$ & $\begin{array}{c}\text { Age } \\
\text { range }\end{array}$ & Study site & Study year & $\begin{array}{l}\text { Study } \\
\text { design }\end{array}$ & $\begin{array}{c}\text { Study } \\
\text { methods }\end{array}$ & Key findings \\
\hline $\begin{array}{l}\text { Rispel et al. } \\
(2011)^{\mathrm{bb}}\end{array}$ & $\begin{array}{l}156 \mathrm{MSM} \\
\text { (FGDs), } \\
285 \mathrm{MSM} \\
\text { (survey) }\end{array}$ & & $\begin{array}{c}\text { Johannesburg, Cape } \\
\text { Town, Durban and } \\
\text { Pietermaritzburg }\end{array}$ & n.d. & RDS & $\begin{array}{l}\text { Survey \& } \\
\text { FGDs }\end{array}$ & $\begin{array}{l}\text { MSM experienced stigma from } \\
\text { health workers. Targeted health } \\
\text { programs for MSM were limited. } \\
57.0 \% \text { used public health services } \\
\text { in the past year, } 69.0 \% \text { did not } \\
\text { have private health insurance. }\end{array}$ \\
\hline $\begin{array}{l}\text { Tucker et al. } \\
(2014)^{\mathrm{cc}} \\
\text { ("Ukwazana") }\end{array}$ & $316 \mathrm{MSM}$ & $18+$ & $\begin{array}{c}\text { Peri-urban } \\
\text { townships, Cape } \\
\text { Town }\end{array}$ & July-October 2010 & $\begin{array}{l}\text { Purposive } \\
\text { sampling }\end{array}$ & Survey & $\begin{array}{l}\text { There was an association found } \\
\text { between homophobia and risk of } \\
\text { UAI for township MSM. }\end{array}$ \\
\hline $\begin{array}{l}\text { Tucker et al. } \\
(2013)^{\mathrm{dd}} \\
(\text { "Ukwazana") }\end{array}$ & $316 \mathrm{MSM}$ & $18+$ & $\begin{array}{c}\text { Peri-urban } \\
\text { townships, Cape } \\
\text { Town }\end{array}$ & July-October 2010 & $\begin{array}{c}\text { Purposive } \\
\text { sampling }\end{array}$ & Survey & $\begin{array}{c}\text { Depression and self-efficacy } \\
\text { predicted UAI. }\end{array}$ \\
\hline $\mathrm{Vu}$ et al. $(2012)^{\mathrm{ee}}$ & $324 \mathrm{MSM}$ & $18+$ & $\begin{array}{c}\text { Urban and peri-urban } \\
\text { Pretoria }\end{array}$ & $\begin{array}{c}\text { February -August } \\
2009\end{array}$ & RDS & Survey & $\begin{array}{l}\text { High levels of internalized } \\
\text { homophobia were found } \\
(10.0-20.0 \%) \text {. Low levels of } \\
\text { education, high levels of HIV } \\
\text { misinformation, bisexuality, and } \\
\text { HIV-related conspiracy beliefs } \\
\text { predicted internalized } \\
\text { homophobia. }\end{array}$ \\
\hline $\begin{array}{l}\text { Lane et al. } \\
(2008)^{\mathrm{ff}}\end{array}$ & $\begin{array}{c}47 \text { MSM } \\
.\end{array}$ & $18+$ & Soweto & $\begin{array}{c}\text { April } 2006 \text {-March } \\
2007\end{array}$ & $\begin{array}{c}\text { Purposive } \\
\text { sampling }\end{array}$ & \begin{tabular}{|c|} 
In-depth \\
interviews and \\
FGDs
\end{tabular} & $\begin{array}{c}\text { MSM reported experiencing } \\
\text { stigma from health care workers. } \\
\text { Non-gay identified MSM hid their } \\
\text { sexuality from health care workers } \\
\text { \& presented heterosexual. }\end{array}$ \\
\hline $\begin{array}{l}\text { Cloete et al. } \\
(2008)^{\mathrm{gg}}\end{array}$ & $\begin{array}{l}92 \text { MSM } \\
\& 330 \\
\text { MSW, all } \\
\text { PLHIV }\end{array}$ & $18+$ & Urban, Cape Town & 2006 & $\begin{array}{c}\text { Purposive } \\
\text { sampling }\end{array}$ & Survey & $\begin{array}{c}57.0 \% \text { internalized HIV-related } \\
\text { stigma was found. No differences } \\
\text { were found between MSM and } \\
\text { men who have sex with women } \\
\text { only. }\end{array}$ \\
\hline $\begin{array}{l}\text { Parry et al. } \\
(2008)^{\mathrm{hh}}\end{array}$ & $\begin{array}{l}109 \text { drug } \\
\text { users (78 } \\
\text { MSM) }\end{array}$ & $18+$ & $\begin{array}{c}\text { Durban, Cape Town, } \\
\text { Pretoria }\end{array}$ & $\begin{array}{c}\text { October-November } \\
2005\end{array}$ & $\begin{array}{l}\text { Snowball } \\
\text { sampling }\end{array}$ & $\begin{array}{l}\text { Observation, } \\
\text { mapping \& } \\
\text { FGDs } \\
\end{array}$ & $\begin{array}{l}\text { HIV prevalence was found to be } \\
35.0 \% \text { among MSM drug users. }\end{array}$ \\
\hline $\begin{array}{l}\text { Parry et al. } \\
(2008)^{\mathrm{ii}}\end{array}$ & $78 \mathrm{MSM}$ & $18+$ & $\begin{array}{c}\text { Durban, Cape Town, } \\
\text { Pretoria }\end{array}$ & Oct-Nov 2005 & $\begin{array}{l}\text { Snowball } \\
\text { sampling }\end{array}$ & $\begin{array}{c}\text { Interviews and } \\
\text { FGDs }\end{array}$ & $\begin{array}{l}\text { Drug use facilitated sexual } \\
\text { encounters \& led to risky sex for } \\
\text { MSM (including inconsistent } \\
\text { condom use). }\end{array}$ \\
\hline
\end{tabular}

${ }^{\mathrm{bb}}[88],{ }^{\mathrm{cc}}[87],{ }^{\mathrm{dd}}[86],{ }^{\mathrm{ec}}[84],{ }^{\mathrm{ff}}[17],{ }^{\mathrm{gg}}[85],{ }^{\mathrm{hh}}[89],{ }^{\mathrm{i}}[90]$

The study of WSW living with HIV in South Africa found that nearly half of the sample $(\mathrm{N}=72)$ had been raped $(45.0 \%)$ or had previously experienced physical inter-partner violence (47.0\%) [92]. Over three quarters (76.0\%) reported having had an STI previously; a third (33.0\%) had engaged in transactional sex; and $15.0 \%$ had a history of IDU. Just under half of the sample reported recent risky sexual behavior with men.

In the qualitative study with 24 self-identified lesbians living with HIV in Namibia, South Africa, and Zimbabwe (16/24 South African), it was found that one in three participants had been raped [41]. Other issues that emerged were barriers in services, misconceptions that lesbians were safe from HIV and poor access to safer sex barriers such as dental dams, finger condoms, and gloves.

\section{HIV Risk Among LGB Youth in South Africa}

Two studies on LGB youth and HIV in South Africa were included, as summarized in Table 6. Both studies were quantitative, included broad samples of adolescents of any sexuality, and were conducted in the urban area of 
Johannesburg $[93,94]$. The first study found that HIV prevalence for LGB youth aged 14 to 19 years was reported to be $14.0 \%(\mathrm{~N}=4 / 29)$ and much higher than the $2.3 \%(\mathrm{n}=8 / 350)$ HIV prevalence found among heterosexual identified youth [93]. However, the sample was not representative and the number of HIV positive cases for LGB youth was small. The second study found that LGB youth aged 16 to 18 years were more likely to engage in HIV risk behaviors compared to their heterosexual peers [94]. Specifically, LGB youth were found to be at greater risk of having a higher number of sex partners and engaging in transactional sex.

Table 5. Literature on HIV risk among lesbian, bisexual and other WSW in South Africa (N=3).

\begin{tabular}{|c|c|c|c|c|c|c|c|}
\hline Source & Sample size & $\begin{array}{c}\text { Age } \\
\text { range }\end{array}$ & Study site & $\begin{array}{c}\text { Study } \\
\text { year }\end{array}$ & Study design & $\begin{array}{c}\text { Study } \\
\text { methods }\end{array}$ & Key findings \\
\hline $\begin{array}{l}\text { Sandfort } \\
\text { et al. } \\
(2013)^{\mathrm{jj}}\end{array}$ & $591 \mathrm{WSW}$ & $\begin{array}{c}18+ \\
\text { years }\end{array}$ & $\begin{array}{c}\text { Botswana, } \\
\text { Namibia, South } \\
\text { Africa, } \\
\text { Zimbabwe } \\
\text { (61.0\% South } \\
\text { African) }\end{array}$ & 2010 & $\begin{array}{l}\text { Convenience } \\
\text { sample }\end{array}$ & Surveys & $\begin{array}{c}\text { Self-reported HIV prevalence was } 9.6 \% \text {. } \\
\text { Approximately } 50.0 \% \text { of WSW had reported } \\
\text { having ever had consensual heterosexual } \\
\text { sex.Transactional sex was reported by nearly } 1 \text { in } 5 \\
\text { WSW. Experience of rape was reported by nearly } 1 \\
\text { in } 3 \text { women. Having been raped by men and/or } \\
\text { women were the only factors independently } \\
\text { associated with HIV prevalence. }\end{array}$ \\
\hline $\begin{array}{l}\text { Matebeni } \\
\text { et al. } \\
(2013)^{\mathrm{kk}}\end{array}$ & \begin{tabular}{|c|}
24 self- \\
identified \\
lesbians, PLHIV
\end{tabular} & $\begin{array}{c}18+ \\
\text { years }\end{array}$ & $\begin{array}{l}\text { Namibia, South } \\
\text { Africa and } \\
\text { Zimbabwe } \\
\text { (16/24 South } \\
\text { African) }\end{array}$ & $2010-11$ & $\begin{array}{l}\text { Community } \\
\text { participatory } \\
\text { approach, } \\
\text { purposive } \\
\text { sampling }\end{array}$ & $\begin{array}{l}\text { In-depth } \\
\text { interviews }\end{array}$ & $\begin{array}{l}\text { Rape was reported by } 1 \text { in } 3(8 / 24) \text { lesbians living } \\
\text { with HIV. Barriers to health services were } \\
\text { identified (providers uninformed, negative } \\
\text { attitudes). The misconception that lesbians are safe } \\
\text { from HIV was a common belief. Safer sex barriers } \\
\text { (dental dams, finger condoms, gloves) were not } \\
\text { freely available. }\end{array}$ \\
\hline $\begin{array}{l}\text { Cloete } \\
\text { et al. } \\
(2011)^{11}\end{array}$ & $\begin{array}{l}72 \text { WSW, } \\
\text { PLHIV }\end{array}$ & $18+$ & $\begin{array}{l}\text { Cape Town, } \\
\text { South Africa }\end{array}$ & 2006 & $\begin{array}{l}\text { Convenience } \\
\text { sampling }\end{array}$ & Surveys & $\begin{array}{c}\text { Of WSW living with HIV: } 76.0 \% \text { reported a } \\
\text { sexually transmitted infection (STI); } 33.0 \% \\
\text { engaged in transactional sex; } 45.0 \% \text { had been } \\
\text { raped; } 47.0 \% \text { had experienced physical intimate } \\
\text { partner violence; } 15.0 \% \text { had a history of IDU; and } \\
\text { just fewer than } 50.0 \% \text { reported recent risky sexual } \\
\text { behavior with men. }\end{array}$ \\
\hline
\end{tabular}

$\mathrm{jij}[91],{ }^{\mathrm{kk}}[41],{ }^{\mathrm{II}}[92]$

Table 6. Literature on HIV risk among LGB (lesbian, gay, bisexual) youth in South Africa (N=2).

\begin{tabular}{|c|c|c|c|c|c|c|c|}
\hline Source & Sample size & $\begin{array}{c}\text { Age } \\
\text { range }\end{array}$ & Study site & Year of study & Study design & $\begin{array}{c}\text { Study } \\
\text { methods }\end{array}$ & Key findings \\
\hline $\begin{array}{c}\text { Thurston } \\
\text { et al. }(2014) \\
{[94]}\end{array}$ & $\begin{array}{c}822 \\
\text { adolescents }\end{array}$ & $\begin{array}{c}16 \text { to } 18 \\
\text { years old }\end{array}$ & $\begin{array}{c}\text { Urban, } \\
\text { Johannesburg }\end{array}$ & $\begin{array}{c}\text { October } 2008 \text { - } \\
\text { November } \\
2009\end{array}$ & $\begin{array}{l}\text { Convenience } \\
\text { sample }\end{array}$ & Surveys & $\begin{array}{l}\text { LGB youth had an increased HIV risk } \\
\text { of having a higher number of sex } \\
\text { partners and to have engaged in } \\
\text { transactional sex relative to their } \\
\text { heterosexual peers. }\end{array}$ \\
\hline $\begin{array}{l}\text { Miller et al. } \\
\text { (2013) [93] }\end{array}$ & $\begin{array}{c}379 \\
\text { adolescents }\end{array}$ & $\begin{array}{c}14 \text { to } 19 \\
\text { years old }\end{array}$ & $\begin{array}{l}\text { Urban, Soweto, } \\
\text { Johannesburg, } \\
\text { South Africa }\end{array}$ & & & Surveys & $\begin{array}{l}\text { A higher percentage of those who } \\
\text { identified as lesbian, gay or bisexual } \\
\text { were HIV positive }(14 \%, 4 / 29) \\
\text { compared to those who identified as } \\
\text { heterosexual }(2.3 \%, 8 / 350) \text {. }\end{array}$ \\
\hline
\end{tabular}

\section{DISCUSSION}

This review points to a recent emergence of empirical HIV research with MSM in South Africa since 2006. However, the findings of this review highlight a paucity of HIV research with WSW and transgender populations. Comprehensive research is needed to understand the risks and drivers of HIV infection in MSM, WSW, and LGBT populations. As noted earlier, without taking MSM, WSW, and LGBT populations and behaviors into account when implementing HIV research, policy, and programs, the response will remain inadequate and may silently contribute to high prevalence of HIV in South Africa.

The increasing number of large-scale research studies investigating HIV among MSM populations show that MSM are a high risk population. Most recently, the Marang Men's Project [28] provided baseline data on HIV prevalence among MSM in Cape Town, Durban, and Johannesburg, the three largest cities of South Africa. Although not reflected in this review as a non-peer reviewed publication, the Marang Men's Project found HIV prevalence among MSM to 
range from $22.3 \%$ in Cape Town, to $26.8 \%$ in Johannesburg, to $48.2 \%$ in Durban [28]. These high prevalence estimates are consistent with studies done elsewhere as reported in this review.

The review also found that there are discrepancies regarding the availability of research on the diversity of MSM populations. Same-sex sexualities are diverse $[95,96]$ and, in many African contexts, men have been found to engage in clandestine same-sex relationships while still fulfilling their expected gender roles and responsibilities [97]. However, this review found that despite the growing number of published articles, the scope of research is still limited. This review found a scarcity of research among MSM living in rural areas, MSM who identify as heterosexual, older MSM, and MSM from race groups other than black South African (i.e. white, coloured, and Indian/Asian).

Only three articles on HIV and WSW populations were found in this review. Their findings all highlighted how lesbian, bisexual and other WSW are at risk of HIV in South Africa. These studies pointed to amplified risk stemming from misconceptions about the realities of female-to-female transmission and from being targeted for sexual violence [10]. Violence against lesbians and WSW was consistently reported in all three studies that were reviewed; reports of rape ranged from a third to a half of the participants [41, 91, 92]. This is an extremely concerning issue that needs urgent attention in research, policy and programs. All three articles reviewed remarked on how lesbians and WSW are ignored in HIV research and prevention programs in South Africa [41, 91, 92]. Despite this existing evidence, WSW remain absent from NSP priorities.

Although this review found two articles that considered LGB youth, both articles were reporting on sub-samples of studies among adolescents generally. These two studies pointed to the higher risk of HIV prevalence and engagement in risk behaviors among LGB youth. As evidence of homophobia has also been found to be prevalent in South African schools [98], it is vital that future research studies in South Africa pursue a further in-depth exploration of LGB youth HIV risks and needs. Transgender youth are also at risk for stigma, transphobia and cissexism which can lead to selfharm and suicide as documented in the United States [99]. The impact of transphobia and cissexism on HIV risk-taking behaviors among youth needs to be explored in the South African context.

This review did not find any peer-reviewed articles on transgender populations and HIV in South Africa. This suggests that although transgender populations have been identified as key populations globally [100] and in the South African 2012-2016 NSP [4] there is a stark gap in the literature. However, Gender Dynamix, a transgender organization in South Africa, has conducted a situational analysis of the health of transgender people including their HIV prevention needs [101]. This study found that transgender people in South Africa had poor experiences accessing health care services including HCT and anti-retroviral treatment (ART), particularly as a result of stigma [101]. The organization found high-risk behavior among transgender people, including unsafe sex, transactional sex, and abuse of alcohol and other substances [101]. The study also reported transgender individuals' experiences of transphobic violence, abuse, and discrimination [101].

A recent study pooled data to estimate global HIV prevalence for transgender women at $19.1 \%$ [14]. This study estimated that the odds of being infected with HIV for transgender women was 48.8 times greater than the general heterosexual population, and the risk remained consistent regardless of country income level [14]. Transgender men are also at risk of HIV. Barriers to sexual negotiation linked to unequal power dynamics, low self-esteem, and need for gender identity affirmation have been identified as factors leading to sexual risk-taking behavior among transgender men [59]. A lack of HIV and sexual health education for transgender men has also been identified and could have implications for HIV risk [60]. Along with lesbian, bisexual, and other WSW, transgender men are at high risk of homophobic and transphobic sexual violence in South Africa, especially black lesbians and transgender men [54]. Given the current limited evidence of HIV risk for transgender populations in South Africa, and international studies showing transgender women are at especially high risk of HIV infection, HIV prevalence estimates and documentation of risk behavior for transgender populations in South Africa is urgently needed.

The limitations of this review include the exclusion of non-peer-reviewed literature, theoretical literature, and articles not focused on social and behavioral aspects of HIV. This review also excluded intersex populations due to the lack of research available on HIV risk among intersex populations internationally.

\section{CONCLUSION}

In the context of a generalized epidemic where the primary mode of HIV transmission is heterosexual, HIV research in South Africa remains overwhelmingly heteronormative, with peer-reviewed articles reflecting a limited number of empirical studies in South Africa on HIV risk for MSM, WSW, and LGBT populations. Although there is now 
increasing attention given to MSM, WSW, and LGBT populations and HIV in South Africa, research remains largely concentrated on MSM. Further research with MSM is encouraged as the complexities of risks still need to be uncovered for this diverse population. Research with lesbian, bisexual, and other WSW as well as with transgender populations is especially needed as there is currently a huge gap in the HIV literature with respect to those at risk populations.

Various research challenges and barriers make it difficult to advance research on HIV risk among MSM, WSW, and LGBT populations in South Africa. For instance, methodological challenges make it difficult to obtain representative samples of MSM, WSW and LGBT populations, particularly as stigma may discourage individuals from disclosing their sexual practices and gender identities to researchers.

Furthermore, western priorities and funders are influential in driving the HIV research agenda on key populations in South Africa and indeed elsewhere. Recently, MSM and, to some extent, transgender populations have made the global research priority list. Lesbian, bisexual, and other WSW remain absent from the global priority list yet evidence suggests they are a high risk population which require attention. Lesbian, bisexual and other WSW, as well as transgender people, are at amplified risk not only due to risk-taking behaviors but also due to targeted sexual violence resulting from homophobia and heterosexism as well as transphobia and cissexism.

In conclusion, HIV research in South Africa should prioritize research with MSM, WSW, and LGBT populations in order to appropriately inform prevention strategies that meet the specific needs of these marginalized populations. Critical reflection among the research community is needed around the issues of who is setting and funding the research agenda and what kind of knowledge is seen as important in order to strive for an inclusive HIV research agenda.

\section{CONFLICT OF INTEREST}

The authors confirm that this article content has no conflict of interest.

\section{ACKNOWLEDGEMENTS}

Decleared none.

\section{REFERENCES}

[1] Shisana O, Rehle T, Simbayi LC, Zuma K, Jooste S. South African National HIV Prevalence, Incidence and Behaviour Survey, 2012. Cape Town: HSRC Press 2014.

[2] Reddy V, Sandfort T, Rispel L. From Social Silence to Social Science: Same-sex sexuality. HIV \& AIDS and Gender in South Africa 2009.

[3] Department of Health. HIV and AIDS and STI National Strategic Plan for South Africa 2007 - 2011. Pretoria 2007.

[4] SANAC.National strategic plan on HIV, STIs and TB 2012-2016. Pretoria 2011.

[5] Republic of South Africa. Civil Union Act, 17 of 2006. Government Gazette.Act 108 of 1996, Pub. L. No. Laws/Statutes 2006; 497(29441)

[6] Republic of South Africa. Constitution of the Republic of South Africa, Act 108 of 1996. In: Government Gazette. Cape Town: Government of the Republic of South Africa 1996; 378.(17678)

[7] Graziano KJ. Reflections from university students in a South African gay and lesbian society. Int J Adv Couns 2005; 27(2): 299-310. [http://dx.doi.org/10.1007/s10447-005-3188-0]

[8] Graziano KJ. Oppression and resiliency in a post-apartheid South Africa: unheard voices of Black gay men and lesbians. Cultur Divers Ethnic Minor Psychol 2004; 10(3): 302-16. [http://dx.doi.org/10.1037/1099-9809.10.3.302] [PMID: 15311981]

[9] Graziano KJ. Coming out on a South African university campus: Adaptations of gay men and lesbians. Soc Transit 2004; 35 (2): $237-87$. [http://dx.doi.org/10.1080/21528586.2004.10419119]

[10] Mkhize N, Bennett J, Reddy V, Moletsane R. The country we want to live in: Hate crimes and homophobia in the lives of black lesbian South Africans. Cape Town: HSRC Press 2010.

[11] Wade AS, Kane CT, Diallo PA, et al. HIV infection and sexually transmitted infections among men who have sex with men in Senegal. AIDS 2005; 19(18): 2133-40. [http://dx.doi.org/10.1097/01.aids.0000194128.97640.07] [PMID: 16284463]

[12] Rawstorne P, Digiusto E, Worth H, Zablotska I. Associations between crystal methamphetamine use and potentially unsafe sexual activity among gay men in Australia. Arch Sex Behav 2007; 36(5): 646-54. [http://dx.doi.org/10.1007/s10508-007-9206-z] [PMID: 17690971]

[13] Beyrer C. HIV epidemiology update and transmission factors: risks and risk contexts-16 ${ }^{\text {th }}$ International AIDS Conference epidemiology plenary. Clin Infect Dis 2007; 44(7): 981-7.

[http://dx.doi.org/10.1086/512371] [PMID: 17342654] 
[14] Baral SD, Poteat T, Strömdahl S, Wirtz AL, Guadamuz TE, Beyrer C. Worldwide burden of HIV in transgender women: a systematic review and meta-analysis. Lancet Infect Dis 2013; 13(3): 214-22. [http://dx.doi.org/10.1016/S1473-3099(12)70315-8] [PMID: 23260128]

[15] McIntyre JA. The need for HIV prevention interventions for men who have sex with men in Africa. Sex Transm Infect 2010; 86(2): 82-3. [http://dx.doi.org/10.1136/sti.2009.041640] [PMID: 20332365]

[16] Sallar AM, Somda DA. Homosexuality and HIV in Africa: An essay on using entertainment education as a vehicle for stigma reduction. Sex Cult 2011; 15(3): 279-309. [http://dx.doi.org/10.1007/s12119-011-9094-1]

[17] Lane T, Mogale T, Struthers H, McIntyre J, Kegeles SM. They see you as a different thing: the experiences of men who have sex with men with healthcare workers in South African township communities. Sex Transm Infect 2008; 84(6): 430-3. [http://dx.doi.org/10.1136/sti.2008.031567] [PMID: 19028941]

[18] Johnson CA. Off the map. How HIV/AIDS programming is failing same-sex practicing people in Africa; New York International Gay and Lesbian Human Rights Commission 2007.

[19] Parker R, Khan S, Aggleton P. Conspicuous by their absence? Men who have sex with men (MSM) in developing countries: implications for HIV prevention. Crit Public Health 1998; 8(4): 329-46.

[http://dx.doi.org/10.1080/09581599808402919]

[20] Lane T, Shade SB, McIntyre J, Morin SF. Alcohol and sexual risk behavior among men who have sex with men in South African township communities. AIDS Behav 2008; 12(4 Suppl.): S78-85. [http://dx.doi.org/10.1007/s10461-008-9389-x] [PMID: 18392672]

[21] Rispel LC, Metcalf CA, Cloete A, Reddy V, Lombard C. HIV prevalence and risk practices among men who have sex with men in two South African cities. J Acquir Immune Defic Syndr 2011; 57(1): 69-76. [http://dx.doi.org/10.1097/QAI.0b013e318211b40a] [PMID: 21297480]

[22] Baral S, Sifakis F, Cleghorn F, Beyrer C. Elevated risk for HIV infection among men who have sex with men in low- and middle-income countries 2000-2006: a systematic review. PLoS Med 2007; 4(12): e339. [http://dx.doi.org/10.1371/journal.pmed.0040339] [PMID: 18052602]

[23] Sanders EJ, Graham SM, Okuku HS, et al. HIV-1 infection in high risk men who have sex with men in Mombasa, Kenya. AIDS 2007; 21(18): 2513-20. [http://dx.doi.org/10.1097/QAD.0b013e3282f2704a] [PMID: 18025888]

[24] Gueboguo C. SIDA et homosexualité (s) en Afrique In: analyse des communications de prévention. Editions L'Harmattan 2009.

[25] Sandfort TG, Nel J, Rich E, Reddy V, Yi H. HIV testing and self-reported HIV status in South African men who have sex with men: results from a community-based survey. Sex Transm Infect 2008; 84(6): 425-9. [http://dx.doi.org/10.1136/sti.2008.031500] [PMID: 19028940]

[26] Smith AD, Tapsoba P, Peshu N, Sanders EJ, Jaffe HW. Men who have sex with men and HIV/AIDS in sub-Saharan Africa. Lancet 2009; 374(9687): 416-22 [http://dx.doi.org/10.1016/S0140-6736(09)61118-1] [PMID: 19616840]

[27] Makofane K, Gueboguo C, Lyons D, Sandfort T. Men who have sex with men inadequately addressed in African AIDS National Strategic Plans. Glob Public Health 2013; 8(2): 129-43. [http://dx.doi.org/10.1080/17441692.2012.749503] [PMID: 23252398]

[28] Cloete A, Simbayi LC, Rehle T, et al. The South African Marang Men's Project: HIV bio-behavioural surveys using respondent-driven sampling conducted among men who have sex with men in Cape Town, Durban and Johannesburg. Cape Town: HSRC Press 2014.

[29] Price MA, Rida W, Mwangome M, et al. Identifying at-risk populations in Kenya and South Africa: HIV incidence in cohorts of men who report sex with men, sex workers, and youth. J Acquir Immune Defic Syndr 2012; 59(2): 185-93. [http://dx.doi.org/10.1097/QAI.0b013e31823d8693] [PMID: 22227488]

[30] Dunkle KL, Jewkes RK, Murdock DW, Sikweyiya Y, Morrell R. Prevalence of consensual male-male sex and sexual violence, and associations with HIV in South Africa: a population based cross-sectional study. PLoS Med 2013; 10(6): e1001472. [http://dx.doi.org/10.1371/journal.pmed.1001472] [PMID: 23853554]

[31] Imrie J, Hoddinott G, Fuller S, Oliver S, Newell ML. Why MSM in rural South African communities should be an HIV prevention research priority. AIDS Behav 2013; 17(Suppl. 1): S70-6. [http://dx.doi.org/10.1007/s10461-012-0356-1] [PMID: 23196857]

[32] Johnson CA. Hearing voices: Unearthing evidence of homosexuality in precolonial Africa. In: The greatest taboo: Homosexuality in Black communities. 2001; pp. 132-48.

[33] Lillah-Chiki R. ay Town, South Africa the township where homosexuals can relax in SA's first 'gay-friendly shebeen. Drum 1999; $16-7$.

[34] Grundlingh L. HIV/AIDS in South Africa: a case of failed responses because of stigmatization, discrimination and morality, $1983-1994$. Contree 1999; 46(46): 55-81.

[PMID: 22103007]

[35] Epprecht M. The "unsaying” of indigenous homosexualities in Zimbabwe: Mapping a blindspot in an African masculinity. J South Afr Stud 
$1998 ; 1-20$

[36] Stein J. The gay community a hidden HIV/AIDS epidemic?. AIDS Bulletin 2001; 10(1): 17-8.

[37] Isaacs G, Miller D. AIDS - Its implications for South African homosexuals and the mediating role of the medical practitioner. South African Med J = Suid-Afrikaanse Tydskrif vir Geneeskunde 1985; 68(5): 327-0.

[38] Epprecht M. "Bisexuality" and the politics of normal in african ethnography. Anthropologica 2006; $187-201$. [http://dx.doi.org/10.2307/25605310]

[39] McKenna N. On the margins: men who have sex with men and HIV in the developing world. London: Panos Institute 1996.

[40] Formby E. Lesbian and bisexual women's human rights, sexual rights and sexual citizenship: negotiating sexual health in England. Cult Health Sex 2011; 13(10): 1165-79.

[http://dx.doi.org/10.1080/13691058.2011.610902] [PMID: 21972785]

[41] Matebeni Z, Reddy V, Sandfort T, Southey-Swartz I. "I thought we are safe": Southern African lesbians' experiences of living with HIV. Cult Health Sex 2014; (15 sup1): 34-47.

[42] Power J, McNair R, Carr S. Absent sexual scripts: lesbian and bisexual women's knowledge, attitudes and action regarding safer sex and sexual health information. Cult Health Sex 2009; 11(1): 67-81. [http://dx.doi.org/10.1080/13691050802541674] [PMID: 19234951]

[43] Richardson D. The social construction of immunity: HIV risk perception and prevention among lesbians and bisexual women. Cult Health Sex 2000; 2(1): 33-49. [http://dx.doi.org/10.1080/136910500300859]

[44] Richters J, Prestage G, Schneider K, Clayton S. Do women use dental dams? Safer sex practices of lesbians and other women who have sex with women. Sex Health 2010; 7(2): 165-9. [http://dx.doi.org/10.1071/SH09072] [PMID: 20465981]

[45] Schick V, Rosenberger JG, Herbenick D, Reece M. Sexual behaviour and risk reduction strategies among a multinational sample of women who have sex with women. Sex Transm Infect 2012; 88(6): 407-12. [http://dx.doi.org/10.1136/sextrans-2011-050404] [PMID: 22563015]

[46] Muzny CA, Harbison HS, Pembleton ES, Hook EW, Austin EL. Misperceptions regarding protective barrier method use for safer sex among African-American women who have sex with women. Sex Health 2013; 10(2): 138-41. [http://dx.doi.org/10.1071/SH12106] [PMID: 23369280]

[47] CDC HIV AIDS Surveill Rep 2007; 1-55.

[48] Roberts SJ, Sorensen L, Patsdaughter CA, Grindel C. Sexual behaviors and sexually transmitted diseases of lesbians: results of the Boston lesbian health project. J Lesbian Stud 2000; 4(3): 49-70. [http://dx.doi.org/10.1300/J155v04n03_03]

[49] Xu F, Sternberg MR, Markowitz LE. Women who have sex with women in the United States: prevalence, sexual behavior and prevalence of herpes simplex virus type 2 infection-results from national health and nutrition examination survey 2001-2006. Sex Transm Dis 2010; 37(7): 407-13.

[PMID: 20531032]

[50] Bailey JV, Farquhar C, Owen C, Whittaker D. Sexual behaviour of lesbians and bisexual women. Sex Trans Infect 2003; 79(2): 147-50. [http://dx.doi.org/10.1136/sti.79.2.147] [PMID: 12690139]

[51] Diamant AL, Schuster MA, McGuigan K, Lever J. Lesbians' sexual history with men: implications for taking a sexual history. Arch Intern Med 1999; 159(22): 2730-6. [http://dx.doi.org/10.1001/archinte.159.22.2730] [PMID: 10597764]

[52] Fethers K, Marks C, Mindel A, Estcourt CS. Sexually transmitted infections and risk behaviours in women who have sex with women. Sex Trans Infect 2000; 76(5): 345-9. [http://dx.doi.org/10.1136/sti.76.5.345] [PMID: 11141849]

[53] Lewis RJ, Milletich RJ, Kelley ML, Woody A. Minority stress, substance use, and intimate partner violence among sexual minority women. Aggress Violent Behav 2012; 17(3): 247-56. [http://dx.doi.org/10.1016/j.avb.2012.02.004]

[54] Nath D, Mthathi S. We'll Show You You're a Woman Violence and discrimination against black lesbians and transgender men in South Africa:. In: Human Rights Watch; 2011.

[55] Desmond Tutu HI. The Policy Brief. Key Populations Key Solutions. In: A Gap Analysis and Recommendations for Key Populations and HIV in South Africa; 2011.

[56] Herbst JH, Jacobs ED, Finlayson TJ, McKleroy VS, Neumann MS, Crepaz N. Estimating HIV prevalence and risk behaviors of transgender persons in the United States: a systematic review. AIDS Behav 2008; 12(1): 1-17. [http://dx.doi.org/10.1007/s10461-007-9299-3] [PMID: 17694429]

[57] Baggaley RF, White RG, Boily MC. HIV transmission risk through anal intercourse: systematic review, meta-analysis and implications for HIV prevention. Int J Epidemiol 2010; 39(4): 1048-63. [http://dx.doi.org/10.1093/ije/dyq057] [PMID: 20406794] 
[58] Kenagy GP, Hsieh CM. The risk less known: female-to-male transgender persons' vulnerability to HIV infection. AIDS Care 2005; 17(2): 195-207. [http://dx.doi.org/10.1080/19540120512331325680] [PMID: 15763714]

[59] Sevelius J. There's no pamphlet for the kind of sex I have: HIV-related risk factors and protective behaviors among transgender men who have sex with nontransgender men. J Assoc Nurses AIDS Care 2009; 20(5): 398-410. [http://dx.doi.org/10.1016/j.jana.2009.06.001] [PMID: 19732698]

[60] Xavier J BJ. Transgender health access in Virginia: Focus group report 2005.

[61] Clements-Nolle K, Marx R, Guzman R, Katz M. HIV prevalence, risk behaviors, health care use, and mental health status of transgender persons: implications for public health intervention. Am J Public Health 2001; 91(6): 915-21. [http://dx.doi.org/10.2105/AJPH.91.6.915] [PMID: 11392934]

[62] Sugano E, Nemoto T, Operario D. The impact of exposure to transphobia on HIV risk behavior in a sample of transgendered women of color in San Francisco. AIDS Behav 2006; 10(2): 217-25. [http://dx.doi.org/10.1007/s10461-005-9040-z] [PMID: 16362237]

[63] Bockting WO, Knudson G, Goldberg JM. Counseling and mental health care for transgender adults and loved ones. Int J Transgenderism 2006; 9(3): 35-82.

[http://dx.doi.org/10.1300/J485v09n03_03]

[64] Beyrer C, Baral SD, van Griensven F, et al. Global epidemiology of HIV infection in men who have sex with men. Lancet 2012; 380(9839): 367-77. [http://dx.doi.org/10.1016/S0140-6736(12)60821-6] [PMID: 22819660]

[65] Lane T, Osmand T, Marr A, et al. The Mpumalanga Men's Study (MPMS): results of a baseline biological and behavioral HIV surveillance survey in two MSM communities in South Africa. PLoS One 2014; 9(11): e111063. [http://dx.doi.org/10.1371/journal.pone.0111063] [PMID: 25401785]

[66] Lane T, Raymond HF, Dladla S, et al. High HIV prevalence among men who have sex with men in Soweto, South Africa: results from the Soweto Men's Study. AIDS Behav 2011; 15(3): 626-34. [http://dx.doi.org/10.1007/s10461-009-9598-y] [PMID: 19662523]

[67] Burrell E, Mark D, Grant R, Wood R, Bekker LG. Sexual risk behaviours and HIV-1 prevalence among urban men who have sex with men in Cape Town, South Africa. Sex Health 2010; 7(2): 149-53. [http://dx.doi.org/10.1071/SH09090] [PMID: 20465978]

[68] Baral S, Burrell E, Scheibe A, Brown B, Beyrer C, Bekker LG. HIV risk and associations of HIV infection among men who have sex with men in peri-urban Cape Town, South Africa. BMC Public Health 2011;11:766 [http://dx.doi.org/10.1186/1471-2458-11-766]

[69] Nyoni JE, Ross MW. Condom use and HIV-related behaviors in urban Tanzanian men who have sex with men: a study of beliefs, HIV knowledge sources, partner interactions and risk behaviors. AIDS Care 2013; 25(2): 223-9. [http://dx.doi.org/10.1080/09540121.2012.699671] [PMID: 22788911]

[70] Sheehy M, Tun W, Vu L, Adebajo S, Obianwu O, Karlyn A. High levels of bisexual behavior and factors associated with bisexual behavior among men having sex with men (MSM) in Nigeria. AIDS Care 2014; 26(1): 116-22. [http://dx.doi.org/10.1080/09540121.2013.802281] [PMID: 23742663]

[71] Jewkes R, Dunkle K, Nduna M, et al. Factors associated with HIV sero-positivity in young, rural South African men. Int J Epidemiol 2006; 35(6): 1455-60.

[http://dx.doi.org/10.1093/ije/dy1217] [PMID: 17030525]

[72] Eaton LA, Pitpitan EV, Kalichman SC, et al. Men who report recent male and female sex partners in Cape Town, South Africa: an understudied and underserved population. Arch Sex Behav 2013; 42(7): 1299-308. [http://dx.doi.org/10.1007/s10508-013-0077-1] [PMID: 23519592]

[73] Arnold MP, Struthers H, McIntyre J, Lane T. Contextual correlates of per partner unprotected anal intercourse rates among MSM in Soweto, South Africa. AIDS Behav 2013; 17(Suppl. 1): S4-11. [http://dx.doi.org/10.1007/s10461-012-0324-9] [PMID: 23054039]

[74] Sandfort T, Yi H, Knox J, Reddy V. Sexual partnership types as determinant of HIV risk in South African MSM: an event-level cluster analysis. AIDS Behav 2013; 17(Suppl. 1): S23-32. [http://dx.doi.org/10.1007/s10461-012-0294-y] [PMID: 22956229]

[75] Jobson G, de Swardt G, Rebe K, Struthers H, McIntyre J. HIV risk and prevention among men who have sex with men (MSM) in peri-urban townships in Cape Town, South Africa. AIDS Behav 2013; 17(Suppl. 1): S12-22. [http://dx.doi.org/10.1007/s10461-012-0328-5] [PMID: 23054040]

[76] Heusser S, Elkonin D. Childhood sexual abuse and HIV sexual-risk behaviour among men who have sex with men in South Africa. S Afr J Psychol 2013. [http://dx.doi.org/10.1177/0081246313516258]

[77] Nel JA, Yi H, Sandfort TG, Rich E. HIV-untested men who have sex with men in South Africa: the perception of not being at risk and fear of being tested. AIDS Behav 2013; 17(1)(Suppl. 1): S51-9. 
[http://dx.doi.org/10.1007/s10461-012-0329-4] [PMID: 23054041]

[78] Stephenson R, Rentsch C, Sullivan P. High levels of acceptability of couples-based HIV testing among MSM in South Africa. AIDS Care 2012; 24(4): 529-35.

[PMID: 22007940]

[79] Stephenson R, Rentsch C, Sullivan P, et al. Attitudes toward couples-based HIV counseling and testing among MSM in Cape Town, South Africa. AIDS Behav 2013; 17(Suppl. 1): S43-50. [http://dx.doi.org/10.1007/s10461-012-0293-z] [PMID: 22961498]

[80] Knox J, Sandfort T, Yi H, Reddy V, Maimane S. Social vulnerability and HIV testing among South African men who have sex with men. Int J STD AIDS 2011; 22(12): 709-13. [http://dx.doi.org/10.1258/ijsa.2011.010350] [PMID: 22174050]

[81] Knox J, Reddy V, Kaighobadi F, Nel D, Sandfort T. Communicating HIV status in sexual interactions: assessing social cognitive constructs, situational factors, and individual characteristics among South African MSM. AIDS Behav 2013; 17(1): 350-9. [http://dx.doi.org/10.1007/s10461-012-0337-4] [PMID: 23065127]

[82] Wagenaar BH, Sullivan PS, Stephenson R. HIV knowledge and associated factors among internet-using men who have sex with men (MSM) in South Africa and the United States. PLoS One 2012; 7(3): e32915. [http://dx.doi.org/10.1371/journal.pone.0032915] [PMID: 22427908]

[83] Tun W, Kellerman S, Maimane S, et al. HIV-related conspiracy beliefs and its relationships with HIV testing and unprotected sex among men who have sex with men in Tshwane (Pretoria), South Africa. AIDS Care 2012; 24(4): 459-67. [PMID: 22084826]

[84] Vu L, Tun W, Sheehy M, Nel D. Levels and correlates of internalized homophobia among men who have sex with men in Pretoria, South Africa. AIDS Behav 2012; 16(3): 717-23. [http://dx.doi.org/10.1007/s10461-011-9948-4] [PMID: 21484279]

[85] Rispel LC, Metcalf CA, Cloete A, Moorman J, Reddy V. You become afraid to tell them that you are gay: health service utilization by men who have sex with men in South African cities. J Public Health Policy 2011; 32(Suppl. 1): S137-51. [http://dx.doi.org/10.1057/jphp.2011.29] [PMID: 21730987]

[86] Cloete A, Simbayi LC, Kalichman SC, Strebel A, Henda N. Stigma and discrimination experiences of HIV-positive men who have sex with men in Cape Town, South Africa. AIDS Care 2008; 20(9): 1105-10. [http://dx.doi.org/10.1080/09540120701842720] [PMID: 18608067]

[87] Tucker A, de Swardt G, Struthers H, McIntyre J. Understanding the needs of township men who have sex with men (MSM) health outreach workers: exploring the interplay between volunteer training, social capital and critical consciousness. AIDS Behav 2013; 17(1)(Suppl. 1): S33-42. [http://dx.doi.org/10.1007/s10461-012-0287-x] [PMID: 22903420]

[88] Tucker A, Liht J, de Swardt G, et al. Homophobic stigma, depression, self-efficacy and unprotected anal intercourse for peri-urban township men who have sex with men in Cape Town, South Africa: a cross-sectional association model. AIDS Care 2014; 26(7): 882-9. [http://dx.doi.org/10.1080/09540121.2013.859652] [PMID: 24295155]

[89] Parry C, Petersen P, Carney T, Dewing S, Needle R. Rapid assessment of drug use and sexual HIV risk patterns among vulnerable drug-using populations in Cape Town, Durban and Pretoria, South Africa. SAHARA J 2008; 5(3): 113-9. [http://dx.doi.org/10.1080/17290376.2008.9724909] [PMID: 18979044]

[90] Parry C, Petersen P, Dewing S, et al. Rapid assessment of drug-related HIV risk among men who have sex with men in three South African cities. Drug Alcohol Depend 2008; 95(1-2): 45-53. [http://dx.doi.org/10.1016/j.drugalcdep.2007.12.005] [PMID: 18242881]

[91] Sandfort TG, Baumann LR, Matebeni Z, Reddy V, Southey-Swartz I. Forced sexual experiences as risk factor for self-reported HIV infection among southern African lesbian and bisexual women. PLoS One 2013; 8(1): e53552. [http://dx.doi.org/10.1371/journal.pone.0053552] [PMID: 23326452]

[92] Cloete A, Sanger N, Simbayi LC. Are HIV positive women who have sex with women (WSW) an unrecognized and neglected HIV risk group in South Africa. J AIDS HIV Res 2011; 3(1): 1-5.

[93] Miller CL, Dietrich J, Nkala B, et al. Implications for HIV prevention: lesbian, gay and bisexual adolescents in urban South Africa are at increased risk of living with HIV. Pediatr Infect Dis J 2013; 32(6): e263-4. [http://dx.doi.org/10.1097/INF.0b013e31828b28f1] [PMID: 23838741]

[94] Thurston IB, Dietrich J, Bogart LM, et al. Correlates of sexual risk among sexual minority and heterosexual South African youths. Am J Public Health 2014; 104(7): 1265-9. [http://dx.doi.org/10.2105/AJPH.2013.301865] [PMID: 24832149]

[95] Teunis N. Same-sex sexuality in Africa: A case study from Senegal. AIDS Behav 2001; 5(2): $173-82$. [http://dx.doi.org/10.1023/A:1011335129358]

[96] Murray SO, Roscoe W. Studies in African homosexualities. Boy-wives and female-husbands; 1998.

[97] Cloete A, Rispel L, Metcalf C, Reddy V. Being straight and being gay: Identity or Multiple Desire: The Case of South Africa. Sexuality in Africa Magazine \& Monographs 2010; pp. 9-10. 
[98] Msibi T. I'm used to it now: experiences of homophobia among queer youth in South African township schools. Gend Educ 2012; 24(5): 515-33.

[http://dx.doi.org/10.1080/09540253.2011.645021]

[99] Grossman AH, D’Augelli AR. Transgender youth and life-threatening behaviors. Suicide Life Threat Behav 2007; $37(5): 527-37$. [http://dx.doi.org/10.1521/suli.2007.37.5.527] [PMID: 17967119]

[100] UNAIDS action framework: Universal access for men who have sex with men, and transgender people 2009.

[101] Stevens M. Transgender access to sexual health services in South Africa. Cape Town: Gender Dynamix 2012.

Received: April 22, 2015

Revised: July 10, 2015

Accepted: October 12, 2015

(C) Evans et al.; Licensee Bentham Open.

This is an open access article licensed under the terms of the Creative Commons Attribution-Non-Commercial 4.0 International Public License (CC BY-NC 4.0) (https://creativecommons.org/licenses/by-nc/4.0/legalcode), which permits unrestricted, non-commercial use, distribution and reproduction in any medium, provided the work is properly cited. 